an open porch. The entablature of this porch was supported by six colossal marble figures, half of them Tritons and half Giants, both types being adaptations from statues of divinities in the pediments of the Parthenon. In front of the pedestals of these colossal figures were placed seated statues of philosophers. From the radical changes involved in the remodelling and from the fact that Philostratos (writing in the late second century) referred to the building as the scene of public lectures by the sophists, it may be inferred that in its second period the Agrippeum had become a university lecture hall and that its function as a concert hall had been assumed by the great new Odeum erected by Herodes on the south slope of the Acropolis about A.D. 160.

A century later (A.D. 267) the Agrippeum was burned down by a band of barbarians, the Heruli, who sacked this part of Athens. The area lay desolate until about A.D. 400. Then above the ruins of the ancient building was erected a huge complex in the nature of a gymnasium which, in accordance with the Greek practice, would also have served university purposes. In the façade of the new building were incorporated four of the colossal figures from the old. The great structure of A.D. 400 was abandoned in the sixth century, presumably in consequence of the Emperor Justinian's edict closing the University of Athens (A.D. 529), and its ruins were buried by silt. Early in the nineteenth century three of the colossal figures were rediscovered and later re-erected, to be known as the 'Stoa of the Giants', one of the most prominent landmarks in the city and one of the most enigmatic until its riddle was solved by the current excavations.

\section{川6 TRAINING FACILITIES IN INDUSTRIAL RADIOLOGY}

T $\mathrm{HE}$ need for extending the available training facilities in industrial radiology was discussed at a meeting of be Industrial Radiology Group of the Institufe 6 Physics held on February 18, at whinh/pre representatives of inspecting authorities, techlical institutions, the Ministry of Education and ind listrial firms.

Discussing the necessity for adequate training of industrial radiographers, Mr. J. C. Rockley (Aeronautical Inspection Department) explained the system adopted by the Department, by which certain industrial radiographic departments and the radiographers in charge are 'approved' after satisfying the Aeronautical Inspection Department that the apparatus available is satisfactory for the intended purpose and that the radiographer has received sufficient basic training to be competent. A feature of this system is that if the radiographer moves to another department, his 'approval' is automatically withdrawn; the 'approval' of the department would also be withdrawn pending the appointment of a qualified successor.

Mr. F. C. Cocks (Lloyd's Register of Shipping) explained that the principal requirements for surveyors and other officers of inspecting authorities are provision for acquiring the technical background and experience in interpretation of radiographs necessary to satisfy themselves on the quality of the radiographic examination, and to assess the effect on the structure examined of an internal defect the shadow of which is seen on the radiograph.
Mr. F. Y. Poynton (Northampton Polytechnic, London) reviewed the present position with regard to technical institutions. Only very few technical colleges-among them the Northampton Polytechnic, London; the Royal Technical College, Glasgow; and the technical colleges at Chesterfield and Wednesbury-possess X-ray apparatus suitable for radiography, and none of these has equipment operating above $100 \mathrm{kV}$. peak. Most of the industrial radiography carried out, however, falls within the range of $150-400 \mathrm{kV}$. peak, or utilizes gamma-radiation; and it is under these conditions that most of the practical problems associated with scattered radiation, radiographic sensitivity and protection occur. Mr. Poynton said that steps are being taken to provide facilities for training in industrial radiography at the Northampton Polytechnic, London. The detailed form of these courses has still to be worked out; but considerable progress has been made in the provision of apparatus and the necessary laboratory and darkroom equipment.

Dr. L. Mullins described the courses being run by Kodak, Ltd., and explained that the basic introductory course occupies two weeks (75 hours) with an optional third week. This period has been adopted as the minimum in which the fundamental theoretical and practical training can be given, and because industrial firms are generally reluctant to release their staff for a longer period. He also mentioned more advanced courses in casting and weld radiography, lasting two weeks, and in shipbuilding radiography occupying three weeks.

Mr. N. Tunstall (Ministry of Education) said that the Ministry is anxious to participate so far as the demand for training facilities justifies; but it is very desirable that industry should make clear to local colleges the extent and nature of the demand for such facilities. The provision of short intensive courses would be a departure from the more usual method of training in a 'laboratory art', which is usually catered for by a course of part-time study lasting two years. The question of awarding a certificate of competence at the end of a full-time course of two or three weeks duration is one requiring a particularly cautious approach. H. S. TASKER

\section{FORTHCOMING EVENTS}

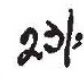

(Meetings marked with an asterisk * are open to the public)

Saturday, April 23-Saturday, April 30

UNIVERSITY I LONDON (at the Institute of Archæology, Inner Circle, Regent' (4ark, London, N.W.1), at 10 a.m. - Public Exhibition of "Giropear/Aousing in Prehistoric Times"."

Monday, April 25

UNIVERSITY OF LONDON (in the Physiology Theatre, University College, Gower Street, London, W.c.1), at 4.45 p.m.- Prof. Adrien Albert: "Selective Toxicity with special reference to Chemotherapy". (Further Lectures on May $2,9,16,23,30$ and June 8 and 13.)

ROYAL SOCIETY OF ARTS (at John Adam Street, Adelphi, London, W.C.2), at 6 p.m.-Mr. H. C.,Walker: "Present Century Advance in Marine Engineering Science" (Science and Marine Navigation, 3). ROYAL INSTITUTE OF CHEMISTRY, LONDON AND S.E. COUNTIES SECTION (at Medway Technical College, Gardiner Street, Gillingham), at 7.30 p.m.-Mr. P. H. Prior : "Some Experiences of a Chemist in the Paper Industry",

ROYAL GEOGRAPHICAL SOCIETY (at Kensington Gore, Jondon,
S.W.7), at 8.15 p.m.-Prof. George B. Cressey : "China's Prospects".

Tuesday, April 26

ROYAL ANThRopoJogical INSTITUTE (at 21 Bedford Square, London, W.C.1), at 5 p.m.-Dr. J. G. Peristiany : "Social Structure of the Pokot (Suk)".

MANCHESTER GeOGRAPHical SocIETY (in the Geographical Hall, St. Mary's Parsonage, Manchester), at 6.30 p.m.-Mr. Harry Milligan : "South Devon Story". 